\title{
The initial hormone receptor/HER2 subtype is the main determinator of subtype discordance in advanced breast cancer: a study of the SONABRE registry
}

\author{
Marissa Meegdes ${ }^{1,2}\left(\right.$ D $\cdot$ Khava I. E. Ibragimova ${ }^{1,2} \cdot$ Dorien J. A. Lobbezoo $^{1} \cdot$ Ingeborg J. H. Vriens $^{1,2}$. \\ Loes F. S. Kooreman ${ }^{2,3} \cdot$ Frans L. G. Erdkamp ${ }^{4} \cdot$ M. Wouter Dercksen ${ }^{5} \cdot$ Birgit E. P. J. Vriens ${ }^{6} \cdot K^{8}$ irsten N. A. Aaldering ${ }^{7}$. \\ Manon J. A. E. Pepels ${ }^{8} \cdot$ Linda M. H. van de Winkel $^{9} \cdot$ Jolien Tol $^{10} \cdot$ Joan B. Heijns ${ }^{11} \cdot$ Agnes J. van de Wouw $^{12}$. \\ Natascha A. J. B. Peters ${ }^{13} \cdot$ Ananda Hochstenbach-Waelen $^{1} \cdot$ Marjolein L. Smidt $^{2,14} \cdot$ Sandra M. E. Geurts ${ }^{1,2}$. \\ Vivianne C. G. Tjan-Heijnen ${ }^{1,2}$
}

Received: 12 October 2021 / Accepted: 1 December 2021 / Published online: 13 January 2022

(c) The Author(s) 2022

\begin{abstract}
Purpose The hormone receptor (HR) and human epidermal growth factor receptor 2 (HER2) are the main parameters in guiding systemic treatment choices in breast cancer, but can change during the disease course. This study aims to evaluate the biopsy rate and receptor subtype discordance rate in patients diagnosed with advanced breast cancer (ABC).

Methods Patients diagnosed with ABC in seven hospitals in 2007-2018 were selected from the SOutheast Netherlands Advanced BREast cancer (SONABRE) registry. Multivariable logistic regression analyses were performed to identify factors influencing biopsy and discordance rates.

Results Overall, $60 \%$ of 2854 patients had a biopsy of a metastatic site at diagnosis. One of the factors associated with a reduced biopsy rate was the HR + /HER2 + primary tumor subtype (versus HR +/HER2- subtype: OR =0.68; 95\% CI: 0.51-0.90). Among the 748 patients with a biopsy of the primary tumor and a metastatic site, the overall receptor discordance rate was $18 \%$. This was the highest for the HR + /HER $2+$ primary tumor subtype, with $55 \%$. In 624 patients with metachronous metastases, the HR + /HER2 + subtype remained the only predictor significantly related to a higher discordance rate, irrespective of prior (neo-)adjuvant therapies (OR=7.49; 95\% CI: 3.69-15.20).

Conclusion The HR +/HER2 + subtype has the highest discordance rate, but the lowest biopsy rate of all four receptor subtypes. Prior systemic therapy was not independently related to subtype discordance. This study highlights the importance of obtaining a biopsy of metastatic disease, especially in the HR + /HER $2+$ subtype to determine the most optimal treatment strategy.
\end{abstract}

Keywords Breast cancer $\cdot$ Metastatic disease $\cdot$ Hormone receptor $\cdot$ HER 2 receptor $\cdot$ Subtype $\cdot$ Biopsy

\section{Introduction}

The systemic therapy choice in patients diagnosed with advanced-metastatic-breast cancer (ABC) is primarily based on the receptor subtype. The receptor subtypes are derived from the hormone receptor (HR) status and human epidermal growth factor receptor 2 (HER2) status, specified as HR + /HER2-, HR + /HER2 +, HR-/HER2 +,

Vivianne C. G. Tjan-Heijnen

vcg.tjan.heijnen@mumc.nl

Extended author information available on the last page of the article and triple negative (TN). In recent years various treatment options became available for ABC. These options have included mTOR, PI3K, and CDK4/6 inhibitors for patients with HR +/HER2- disease [1-3], HER2-targeted therapies for HER2 + disease [4-8], PARP inhibitors for patients with BRCA1/2 mutated, HER2-negative disease [9], and checkpoint inhibitors for PD-L1-positive TN disease [10]. Following these developments, it has become increasingly important to determine the receptor subtype of the tumor in guiding systemic treatment choices.

The receptor subtype of a recurrent tumor site can, however, be different from the receptor subtype of the primary tumor, referred to as subtype discordance. Several studies 
have reported varying discordance rates for the estrogen receptor (ER), progesterone receptor (PR), and HER2 status between primary breast tumor and loco-regional or distant recurrences. A recent meta-analysis, including 39 prospective and retrospective studies, found discordance rates between the primary tumor and the metastatic site of $19 \%$ for ER, 31\% for PR, and $10 \%$ for HER2, respectively [11]. This growing knowledge about high receptor discordance rates has resulted in a worldwide consensus on the importance of obtaining tissue of a metastatic site [12]. In the Netherlands, this led to an explicit recommendation in 2012 that, whenever possible, the initial metastatic site needs to be biopsied for receptor assessment apart from confirming presence of metastatic disease [13]. In terms of its clinical implication, a change in receptor subtype often leads to an adjustment of the treatment strategy. A pooled analysis of the prospective BRITS and DESTINY trials, including 289 patients with suspected breast cancer recurrence (loco-regional recurrence and distant recurrence), revealed that the systemic treatment choice was adjusted in $14 \%$ of patients when biopsy results of the recurrent disease became available [14].

Important limitations of prior studies reporting on subtype discordance are the focus on specific metastatic sites or both loco-regional recurrences and metastatic sites in their study sample [15-22] and a small sample size for regression and subgroup analysis [23-25]. Considering these issues, we present a large real-world study, including all patients diagnosed with $\mathrm{ABC}$, irrespective of metastatic sites and systemic treatment given. We aimed to assess the biopsy rate and the factors associated with taking a biopsy of a metastatic site at $\mathrm{ABC}$ diagnosis. Next, we aimed to determine the receptor subtype discordance rate between the primary tumor and a metastasis. Finally, we aimed to evaluate firstline systemic treatment choices in relation to the occurrence of subtype discordance.

\section{Methods}

\section{Southeast Netherlands advanced BREast cancer (SONABRE) registry}

Data for this study were obtained from the SONABRE Registry (NCT-03577197), an observational cohort study aiming to include all patients aged 18 years and above, with de novo or recurrent $\mathrm{ABC}$ in the Southeast of the Netherlands. Specially trained registrars retrospectively collected data from medical files, including patient and tumor characteristics and treatment information (i.e., local and systemic therapy) for both primary tumor and metastatic disease. The Medical Research Ethics Committee of Maastricht University Medical Center + approved the registry (15-4-239).

\section{Patient selection}

For this study, we selected all patients diagnosed with $\mathrm{ABC}$ in 2007-2018 from seven hospitals, including one academic, four teaching, and two non-teaching hospitals. All patients were eligible for assessing the biopsy rate at time of $\mathrm{ABC}$ diagnosis. For assessing receptor and subtype discordance rates, only patients with a known subtype of both the primary tumor and a metastatic site at time of ABC diagnosis were eligible.

\section{Definitions}

Resection material, or if unavailable biopsy tissue, of the primary tumor was used to determine the subtype of the primary tumor. HER 2 positivity was defined as a positive in situ hybridization (ISH) result or immunohistochemistry (IHC) score of $3+$. If the HER2 status was not reported, but HER2-targeted therapy was given in the (neo-)adjuvant setting, HER2 status was considered positive. ER and PR positivity were defined as positive nuclear staining of $\geq 10 \%$. HR status was considered positive in case of ER and/or PR positivity and ER result was leading in the absence of PR status. When ER status of the primary tumor was unknown and $A B C$ diagnosis was since the year 2002, ER receptor was considered positive when endocrine therapy was given in (neo-)adjuvant setting. Metastatic-free interval (MFI) was defined as the interval between date of primary tumor diagnosis and date of $\mathrm{ABC}$ diagnosis.

\section{Endpoints and statistical analyses}

The first study goal was to determine the proportion of patients with a biopsy assessment of a metastatic site at $\mathrm{ABC}$ diagnosis. A multivariable logistic regression analysis was used to examine the following pre-specified factors possibly associated with a biopsy assessment: period of $\mathrm{ABC}$ diagnosis, age at $\mathrm{ABC}$ diagnosis, subtype of primary tumor, metastatic site, number of primary tumors, and metastaticfree interval (MFI).

The second study goal was to define subtype concordance and discordance rates for patients with complete information on the receptor subtype of both the primary tumor and a metastatic site at time of $\mathrm{ABC}$ diagnosis. Patients with two or more primary tumors with different subtypes were excluded from this analysis. A univariable logistic regression analysis was performed to find associated predictors for discordance based on prior research, including age, WHO performance status, genetic mutation, histology and subtype of the primary tumor, and MFI [21, 24-26]. Additionally, a separate analysis was performed including the type of 
adjuvant therapies while excluding patients with de novo ABC. All potential predictors with a $P$ value of $<0.2$ in the univariable analyses were included in the main multivariable model. All reported $P$ values are two-sided and considered borderline significant at a value of $\leq 0.10$ and statistically significant at $\leq 0.05$.

Lastly, we selected the primary receptor subtype where discordance was most prevalent and described the initial systemic treatment choices per metastatic receptor subtype.

\section{Results}

\section{Patient and tumor characteristics}

Among the 2854 patients included, $75 \%$ were younger than 75 years and $79 \%$ had a good performance status (WHO 0-1) at diagnosis of ABC (Table 1). The large majority $(84 \%)$ had a primary breast cancer diagnosis since the year 2000 and $65 \%$ had a HR +/HER2- primary tumor subtype. Twenty-three percent of patients had de novo ABC and $42 \%$ a MFI over 60 months and $27 \%$ had bone-only metastatic disease and $11 \%$ only visceral metastases. Of patients with metachronous metastases, $76 \%$ had received (neo-)adjuvant systemic therapy.

\section{Biopsy assessment}

Overall, $60 \%$ of patients had a biopsy of a metastatic site at presentation. Per type of hospital, biopsy rate was $73 \%$ in the academic center, $60 \%$ in teaching hospitals, and $50 \%$ in non-teaching hospitals. A more recent period of $\mathrm{ABC}$ diagnosis was associated with a higher biopsy rate: $67 \%$ in 2016-2018 compared with 51\% in 2007-2009 (OR =2.14; 95\% CI: 1.70-2.70) (Fig. 1). An independent higher biopsy rate of distant disease was further observed in younger patients $(56-75$ years versus $>75$ years: OR $=1.80 ; 95 \%$ CI: $1.48-2.19 ; \leq 55$ years versus $>75$ years: $\mathrm{OR}=2.20$; 95\% CI: 1.74-2.78), a metastatic site other than bone-only (e.g., for soft tissue only (OR 3.23=95\% CI: 2.03-5.16) and for visceral disease only $(\mathrm{OR}=2.73 ; 95 \% \mathrm{CI}: 2.04-3.64)$ ), and a longer MFI time compared with de novo ABC (e.g., MFI 3-24 months $(\mathrm{OR}=1.60 ; 95 \% \mathrm{CI}: 1.22-2.10)$ and $\mathrm{MFI} \geq 60$ months $(\mathrm{OR}=4.05$; 95\% CI: 3.18-5.15)). Furthermore, the HR +/HER 2 + primary tumor subtype showed a reduced biopsy rate, as compared with the HR +/HER2- primary tumor subtype $(\mathrm{OR}=0.68 ; 95 \% \mathrm{CI}$ : 0.51-0.90).

\section{Subtype discordance rates}

After excluding 1712 patients with an incomplete receptor status of the metastasis, 362 patients with an incomplete receptor status of the primary tumor and 32 patients with two different primary tumor subtypes, 748 patients were eligible to study concordance and discordance rates between the metastasis and primary tumor (Table 1, Supplementary Figure S1). Among these patients, the overall receptor discordance rate was $18 \%$ (discordance rates for the individual receptors are presented in Supplementary Table S1). Discordance rates were $13 \%$ for HR + /HER2-, $15 \%$ for HR-/HER $2+, 12 \%$ for TN disease, and a high rate of $55 \%$ for $\mathrm{HR}+/ \mathrm{HER} 2+$ (Fig. 2, Supplementary Table S2). Patients with HR + /HER2 + disease converted mainly to HR + /HER2- disease (26\%), followed by HR-/ HER $2+$ disease $(21 \%)$ and less often to TN disease $(8 \%)$. Patients with HR + /HER2- and HR-/HER2 + disease converted mainly to TN disease (both $9 \%$ ) and patients with TN disease converted mainly to HR + /HER2- disease $(8 \%)$. The main predictor for discordance of receptor subtype between primary tumor and metastatic site was the HR + /HER $2+$ subtype of the primary tumor (versus HR + /HER2-: OR = 8.47; 95\% CI: 5.09-14.08), followed by a MFI of 3-24 months (versus de novo: OR $=2.53 ; 95 \%$ CI: 1.16-5.53) (Fig. 3).

In the 624 patients diagnosed with metachronous metastases (excluding de novo ABC), prior HER2-targeted therapy in the adjuvant setting was associated with a threefold higher risk of discordance (versus no HER2targeted: $\mathrm{OR}=3.60$; 95\% CI: 2.05-6.35) (Table 2). However, after correcting for subtype and MFI, prior systemic treatment was no longer significantly associated with a higher incidence of discordance. The HR + /HER $2+$ subtype remained the only predictor significantly related to a higher discordance rate ( $\mathrm{OR}=7.49,95 \% \mathrm{CI}$ : 3.69-15.20). In addition, within the HR + /HER2 + subtype prior systemic treatment was not associated with a higher discordance rate (data not further shown).

\section{First-line treatment choices}

First-line palliative systemic treatment choices were evaluated for the 91 patients with the $\mathrm{HR}+/ \mathrm{HER} 2+$ primary tumor subtype, where discordance was most prevalent. Of 41 patients with a concordant HR + /HER 2 + subtype, the majority started with HER2-targeted therapy (83\%), followed by first-line endocrine therapy (15\%) (Fig. 4). Of 24 patients with receptor subtype changed into the $\mathrm{HR}+/ \mathrm{HER} 2$ - subtype, $67 \%$ received first-line endocrine therapy and $29 \%$ chemotherapy. Of 19 patients with receptor subtype changed into the HR-/HER2 + subtype, 79\% received HER2-targeted therapy and $11 \%$ chemotherapy. Of 7 patients with receptor subtype changed into the TN subtype, 57\% received chemotherapy and 29\% HER2targeted therapy. 
Table 1 Baseline characteristics of patients at moment of $\mathrm{ABC}$ diagnosis, for the total group and the subgroup of patients with known subtype of the primary tumor and an initial metastatic site

\begin{tabular}{|c|c|c|}
\hline & Total & $\begin{array}{l}\text { Known subtype } \\
\text { of pri- } \\
\text { mary tumor } \\
\text { and metastatic } \\
\text { lesion }\end{array}$ \\
\hline & $N=2854$ & $N=748$ \\
\hline & $N(\%)$ & $N(\%)$ \\
\hline \multicolumn{3}{|l|}{ Gender } \\
\hline Female & $2828(99)$ & $741(99)$ \\
\hline \multicolumn{3}{|l|}{ Age at $\mathrm{ABC}$ diagnosis } \\
\hline Median age (IQR) & $65(55-75)$ & $62(52-72)$ \\
\hline $18-55$ years & $710(25)$ & $249(33)$ \\
\hline $56-75$ years & $1421(50)$ & $377(51)$ \\
\hline$>75$ years & $723(25)$ & $122(16)$ \\
\hline \multicolumn{3}{|c|}{ Comorbidity at $\mathrm{ABC}$ diagnosis } \\
\hline Any & $1567(55)$ & $359(48)$ \\
\hline \multicolumn{3}{|c|}{ WHO performance score at $\mathrm{ABC}$ diagnosis } \\
\hline WHO 0-1 & $1540(79)$ & $500(85)$ \\
\hline $\mathrm{WHO} \geq 2$ & $417(21)$ & $91(15)$ \\
\hline Unknown & 897 & 157 \\
\hline \multicolumn{3}{|c|}{ Period of primary breast cancer diagnosis } \\
\hline$<1990$ & $84(3)$ & $4(1)$ \\
\hline 1990-1999 & $388(13)$ & $22(3)$ \\
\hline 2000-2009 & $1306(46)$ & $354(47)$ \\
\hline 2010-2018 & $1076(38)$ & $368(49)$ \\
\hline \multicolumn{3}{|c|}{ Period of $\mathrm{ABC}$ diagnosis } \\
\hline $2007-2009$ & $715(25)$ & $97(13)$ \\
\hline 2010-2012 & $663(23)$ & 139 (19) \\
\hline 2013-2015 & $747(26)$ & $251(33)$ \\
\hline 2016-2018 & 729 (26) & $261(35)$ \\
\hline \multicolumn{3}{|c|}{ Histology primary tumor } \\
\hline Ductal & $2152(75)$ & $608(81)$ \\
\hline Lobular & $511(18)$ & $117(16)$ \\
\hline Other/unknown & $191(7)$ & $23(3)$ \\
\hline \multicolumn{3}{|c|}{ Number of primary tumors } \\
\hline 1 & $2492(87)$ & $709(95)$ \\
\hline$\geq 2$ & $362(13)$ & $39(5)$ \\
\hline \multicolumn{3}{|c|}{ Subtype primary tumor } \\
\hline $\mathrm{HR}+/ \mathrm{HER} 2-$ & $1397(65)$ & $508(68)$ \\
\hline $\mathrm{HR}+/ \mathrm{HER} 2+$ & $276(13)$ & $91(12)$ \\
\hline HR-/HER2 + & $154(7)$ & $53(7)$ \\
\hline $\mathrm{TN}$ & $323(15)$ & $96(13)$ \\
\hline Unknown & 704 & N.A \\
\hline $\mathrm{HR}+/ \mathrm{HER} 2 ?$ & 488 & N.A \\
\hline HR-/HER2? & 45 & N.A \\
\hline HR unknown & 171 & N.A \\
\hline \multicolumn{3}{|c|}{ Number of metastatic sites } \\
\hline Single & $1281(45)$ & $296(40)$ \\
\hline Multiple & $1573(55)$ & $452(60)$ \\
\hline \multicolumn{3}{|l|}{ Initial metastatic sites } \\
\hline Bone only & 779 (27) & $162(22)$ \\
\hline Soft tissue only & $113(4)$ & $35(5)$ \\
\hline
\end{tabular}


Table 1 (continued)

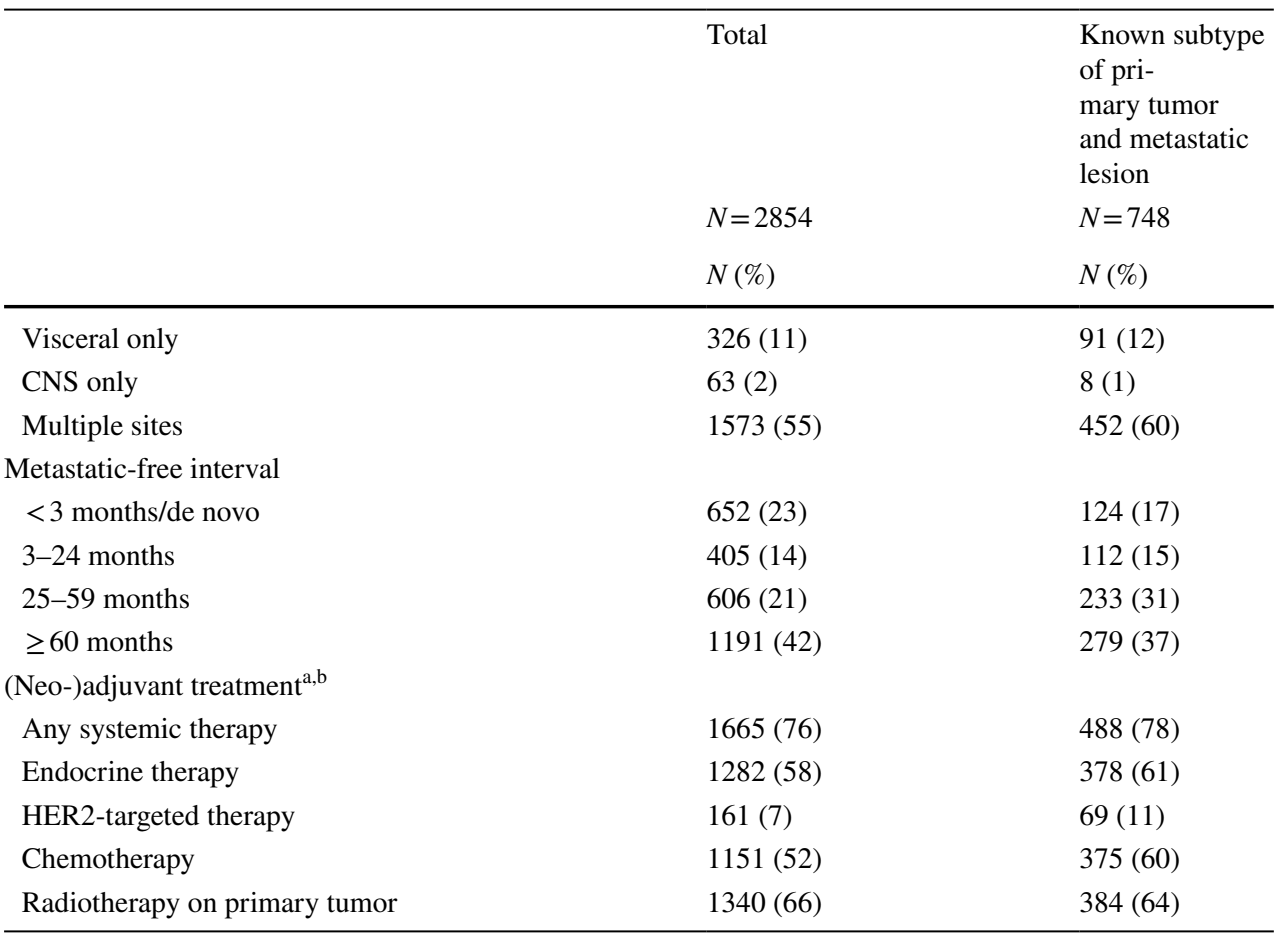

$A B C$ advanced breast cancer, $C N S$ central nervous system, HER2 Human Epidermal growth factor Receptor 2, $H R$ hormone receptor, $I Q R$ interquartile range, $N . A$. not applicable, $T N$ triple negative, $W H O$ World Health Organization

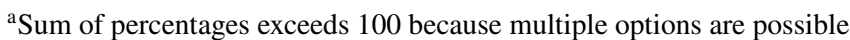

${ }^{\mathrm{b}}$ Among patients with recurrent metastases only (excluding patients with de novo $\mathrm{ABC}$ )

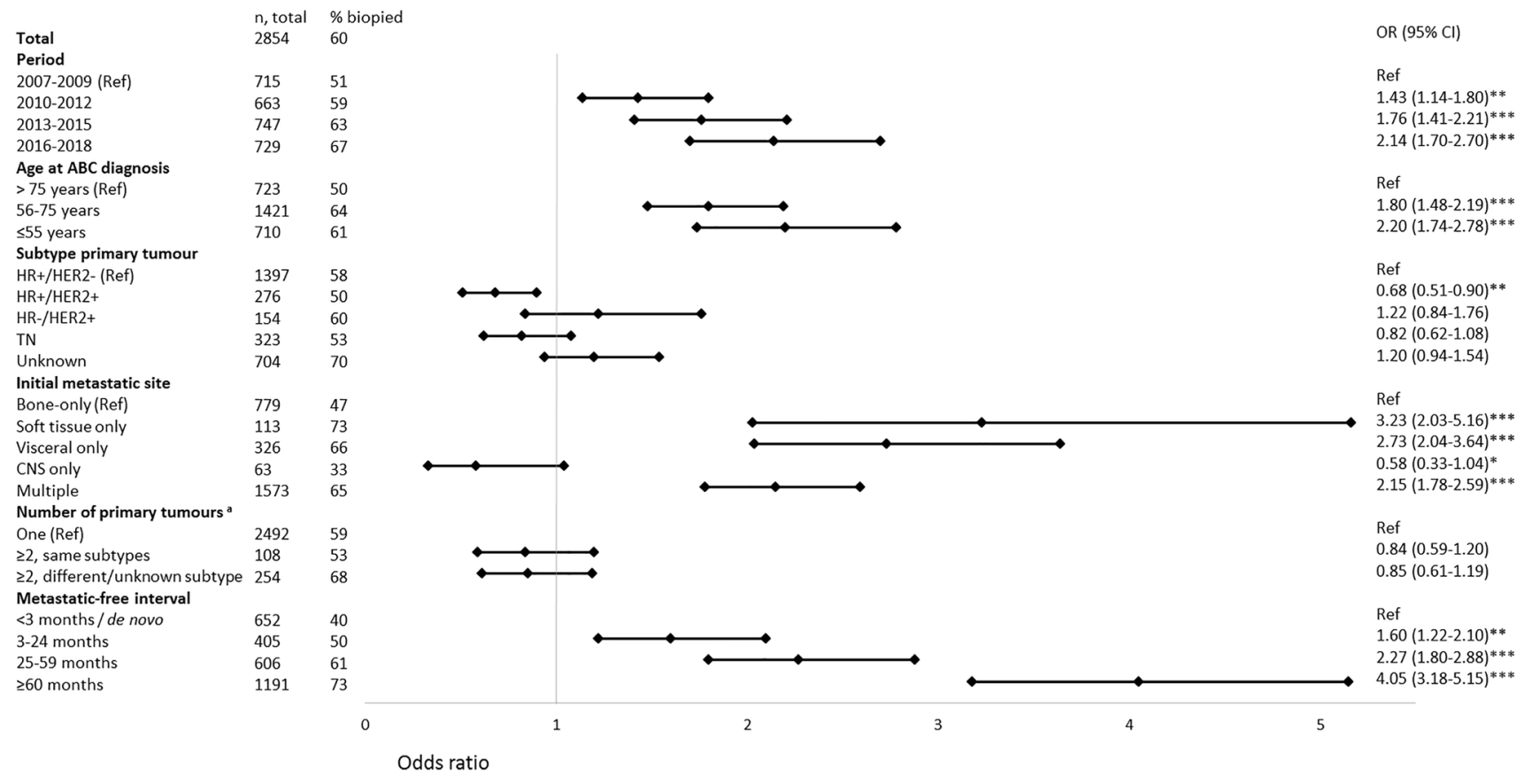

Fig. 1 Factors associated with undergoing a biopsy of a metastatic site at time of $\mathrm{ABC}$ diagnosis, by multivariable logistic regression analysis. ${ }^{\mathrm{a}}$ In case of two or more primary tumors, the subtype of the first primary tumor is reported. *Not statistically significant, but borderline $(P<0.10), * * P<0.05$, *** $P<0.001$ 


\section{HR+/HER2- $(\mathrm{N}=508)$}

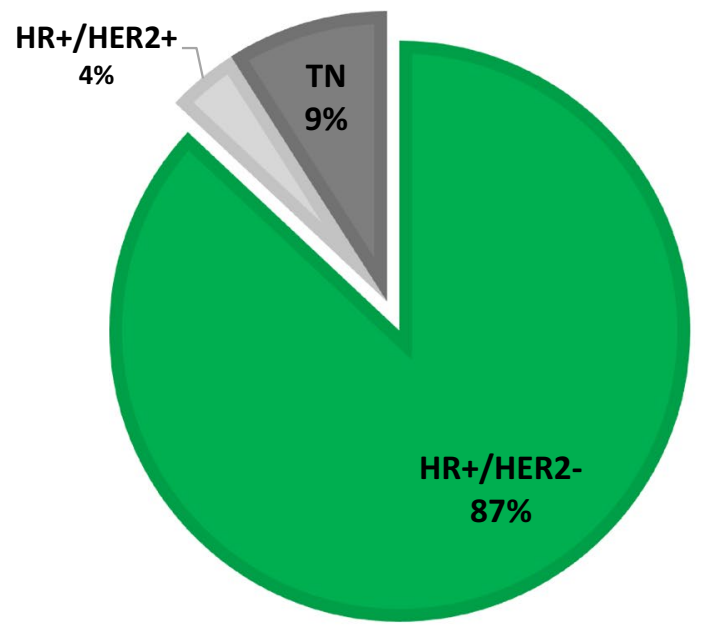

HR-/HER2+ $(\mathrm{N}=53)$

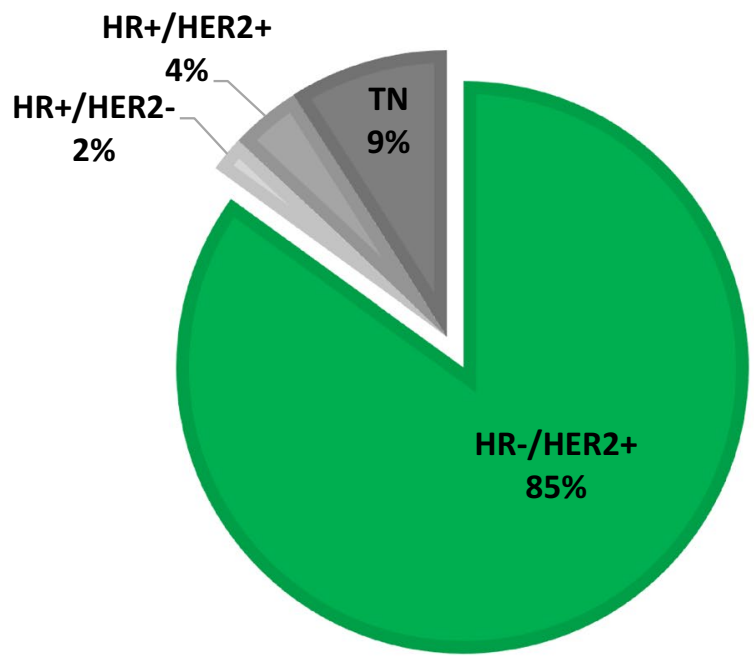

\section{$\mathrm{HR}+/ \mathrm{HER} 2+(\mathrm{N}=91)$}

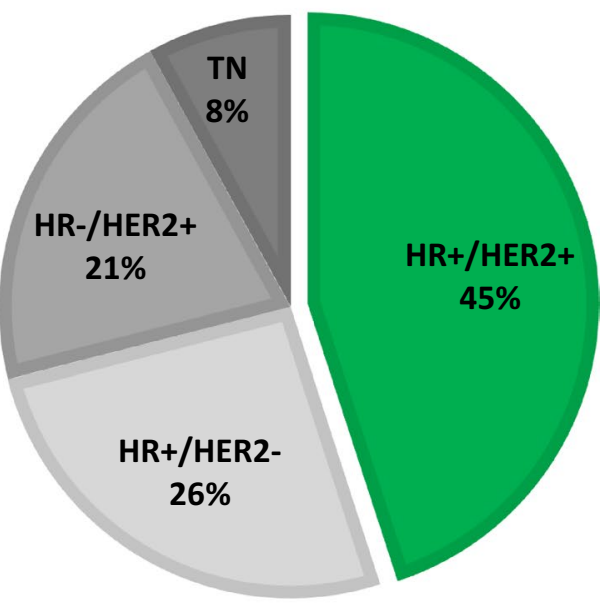

TN (N=96)

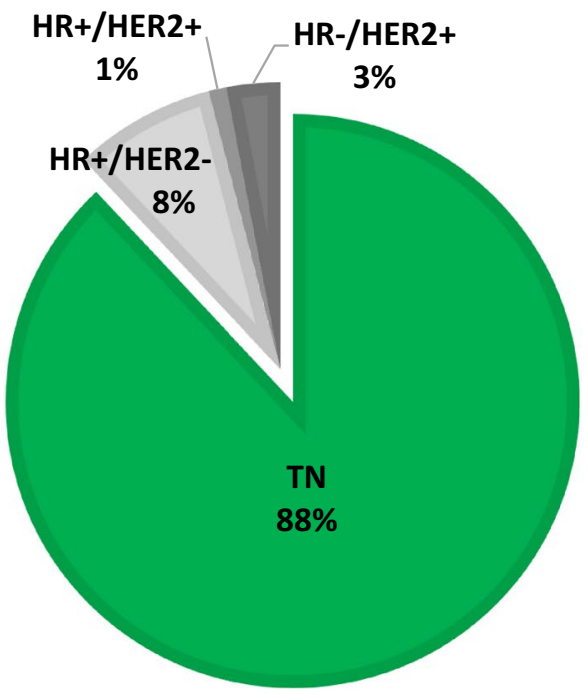

Fig. 2 Subtype of the metastatic lesion per primary tumor subtype $(n=748)$

\section{Discussion}

This study presents real-world data from the SONABRE registry on the biopsy rate of metastatic disease and receptor subtype discordance rate in 2854 patients diagnosed with ABC in 2007-2018. We demonstrated an overall biopsy rate of $60 \%$ and an overall subtype discordance rate of $18 \%$. Surprisingly, the discordance rate in the HR + /HER 2 + subtype was 55\%. The HR + /HER 2 + subtype itself was an independent predictor for subtype discordance, with no relation with prior adjuvant systemic therapies.
A biopsy at time of $\mathrm{ABC}$ diagnosis is recommended to confirm the diagnosis of breast cancer and to determine if subtype conversion has occurred [12]. We found a biopsy rate of $65 \%$ in all patients developing metastatic disease since 2013. It is a positive finding that the biopsy rate in our study increased over time, possibly as a result of the 2012 updated guideline, including the advice to biopsy a metastasis to confirm and characterize metastatic disease. Apart from the effects of the national breast cancer guideline revision itself, other factors may have contributed to the increasing biopsy rate. The hospitals included in the study are nearly all part of a regional cancer collaboration, OncoZON 


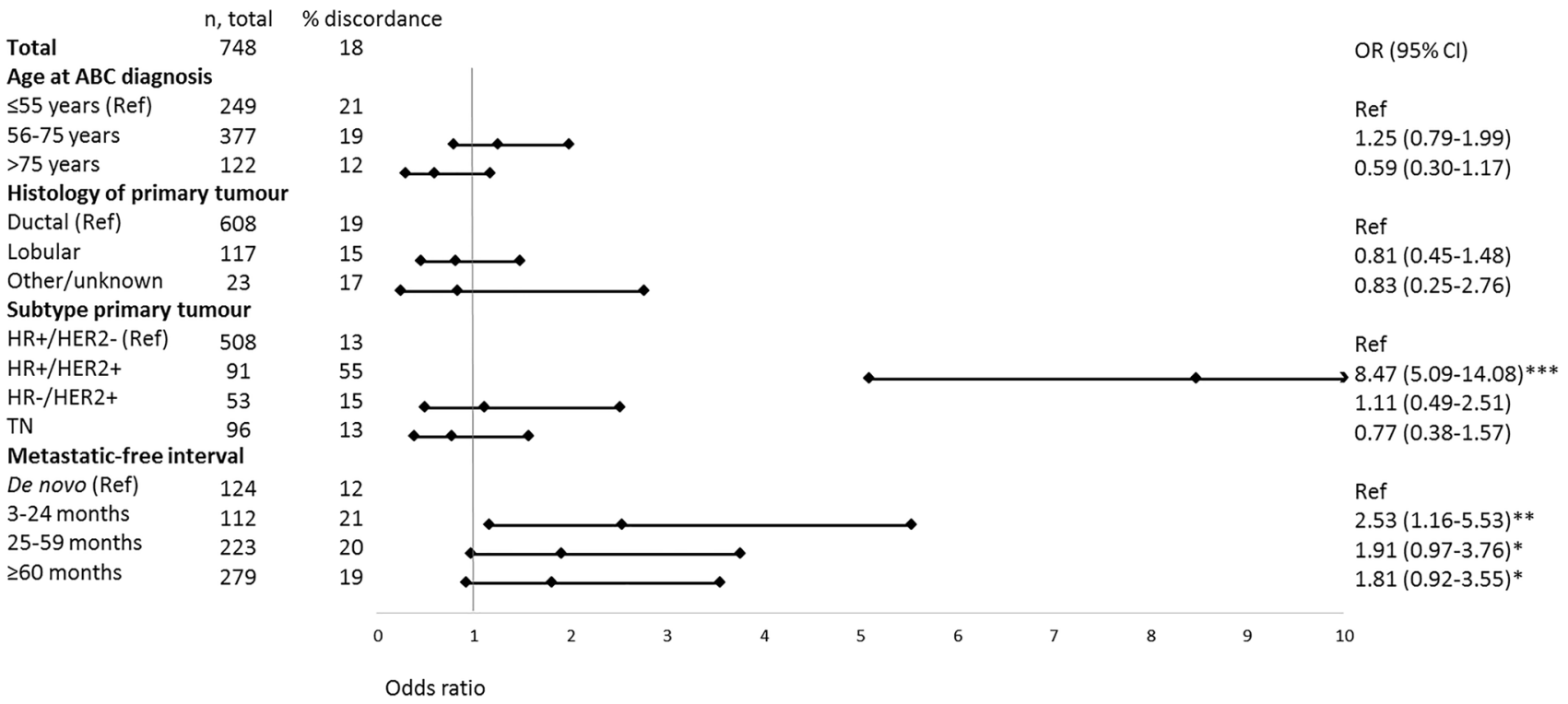

Fig. 3 Factors associated with subtype discordance between the primary tumor and the metastatic site at time of ABC diagnosis, by multivariable logistic regression analysis. *Not statistically significant, but borderline $(P<0.10),{ }^{* *} P<0.05$, *** $P<0.001$

Table 2 The impact of (neo-) adjuvant therapy on subtype discordance among patients with recurrent $\mathrm{ABC}(\mathrm{n}=624)$ (de novo metastatic disease excluded), multivariable analyses without and with adjustment for receptor subtype, and metastatic-free interval (MFI)

\begin{tabular}{|c|c|c|c|c|}
\hline \multirow[t]{3}{*}{ Predictors } & \multirow{3}{*}{$\begin{array}{l}\begin{array}{l}\text { Num- } \\
\text { ber of } \\
\text { patients }\end{array} \\
N\end{array}$} & \multirow{3}{*}{$\begin{array}{l}\text { Number of } \\
\text { discordance }\end{array}$} & \multicolumn{2}{|l|}{ Multivariable analyses } \\
\hline & & & Adjuvant therapies & $\begin{array}{l}\text { Adjuvant therapies } \\
\text { adjusted for subtype } \\
\text { and MFI }\end{array}$ \\
\hline & & & OR $(95 \% \mathrm{CI})$ & OR (95\% CI) \\
\hline \multicolumn{5}{|c|}{ Adjuvant endocrine therapy } \\
\hline No & 246 & $40(16)$ & Ref & Ref \\
\hline Yes & 378 & $83(22)$ & $1.46(0.94-2.27)^{*}$ & $0.97(0.51-1.84)$ \\
\hline \multicolumn{5}{|c|}{ Adjuvant HER2-targeted therapy } \\
\hline No & 555 & $93(17)$ & Ref & Ref \\
\hline Yes & 69 & $30(44)$ & $3.61(2.05-6.35)^{* * *}$ & $0.88(0.37-2.09)$ \\
\hline \multicolumn{5}{|c|}{ Adjuvant chemotherapy alone } \\
\hline No & 249 & $36(15)$ & Ref & Ref \\
\hline Yes & 375 & $87(23)$ & $1.22(0.76-1.96)$ & $1.73(0.99-3.01)^{*}$ \\
\hline Subtype primary tumor & & & - & \\
\hline HR + /HER2- & 423 & $62(15)$ & & Ref \\
\hline $\mathrm{HR}+/ \mathrm{HER} 2+$ & 76 & $43(57)$ & & $7.49(3.69-15.20)^{* * *}$ \\
\hline HR-/HER2 + & 41 & $7(17)$ & & $1.10(0.35-3.44)$ \\
\hline $\mathrm{TN}$ & 84 & $11(13)$ & & $0.65(0.26-1.67)$ \\
\hline MFI & & & - & \\
\hline $3-24$ months & 112 & $23(21)$ & & Ref \\
\hline $25-59$ months & 233 & $47(20)$ & & $0.76(0.41-1.42)$ \\
\hline$\geq 60$ months & 279 & $53(19)$ & & $0.70(0.38-1.32)$ \\
\hline
\end{tabular}

$A B C$ advanced breast cancer, HER2 Human Epidermal growth factor Receptor 2, $H R$ hormone receptor, $M F I$ metastatic-free interval, $O R$ odds ratio

*Not statistically significant, but borderline $(P<0.10)$, ** $P<0.05$, *** $P<0.001$ 


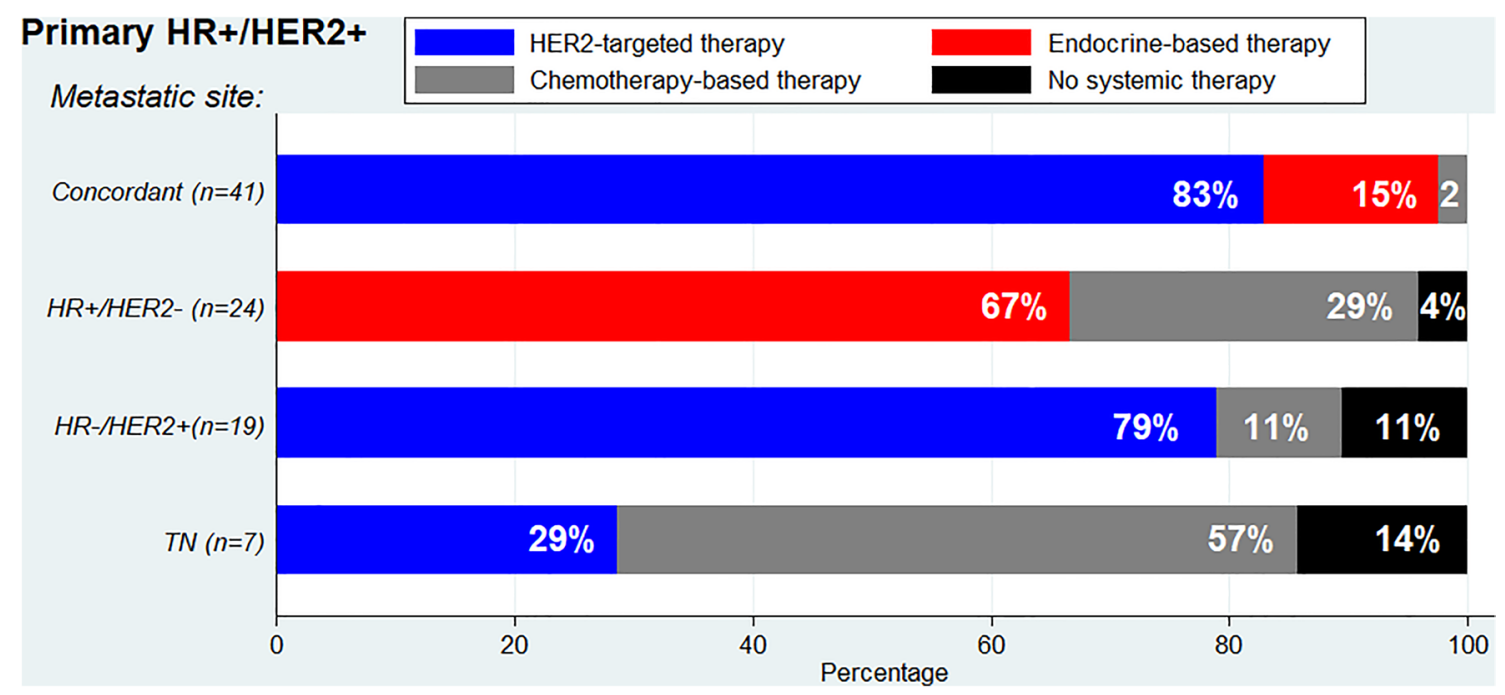

Fig. 4 First treatment choice for concordant and discordant subtype of metastatic site in primary HR +/HER2 + subtype

(Oncologic network Southeast Netherlands), and new guidelines are discussed in the OncoZON meetings. Next to this, enrollment in clinical studies more and more requires the obtainment of metastatic tissue, which might have increased the eagerness and rationale of a standard biopsy. More biopsies of a metastasis were obtained in patients with a longer metastatic-free interval, probably because the physician wanted to be certain of breast cancer recurrence. However, similar to prior studies, our results indicate that patients with a MFI of 3-24 months have an even high to higher risk of discordance, suggesting that conversion occurs more in fast-growing tumors [21, 24, 26]. This finding emphasizes the importance of increasing the use of biopsy assessments in daily clinical practice. In line with this recommendation, Criscitiello et al. have reviewed the pros and cons of metastatic biopsies, concluding that biopsies are needed to evaluate the molecular profile in patients to make an appropriate treatment plan [27].

In general, discordance between two biopsies of breast cancer disease could be explained by a measurement error. The possibility of a measurement error caused by limited diagnostic accuracy accounts for $5 \%-25 \%$ of discordance [28-30]. However, measurement errors alone do not explain the higher prevalence of the loss of a positive receptor rather than finding a new receptor positivity. Alternatively, breast cancer is known to be a heterogenic disease, meaning that different cell lines occur in terms of genetic and phenotypic features [31]. It is theorized that heterogeneity in one tumor consists of two different types: spatial heterogeneity and temporal heterogeneity [32]. Spatial heterogeneity refers to different cancer clones that vary in histologic or cellular morphology in different positions within a tumor localization or between metastases $[31,33]$. Temporal heterogeneity describes the change of a tumor over time as an evolutionary process of tumor composition due to specific influencing factors as stress, tumor biological drift, and given therapies $[27,34]$. Our study shows that subtype discordance was most prevalent in the HR +/HER2 + subtype, while earlier given (neo-)adjuvant systemic therapies were not related to discordance in the multivariate analysis. This result weakens the general assumption that therapeutic pressure is thought to have the biggest influence on receptor loss. We hypothesize that cross-talk between the ER and HER2 receptor stimulates discordance. It is assumed that ER expression leads to inhibition of the PI3K pathway and subsequently decreases the HER2 signal activity [35, 36]. Vice versa, amplified HER2 signal activity leads to a down-regulation of ER expression [37]. Nevertheless, the specific explanation for different subtypes within a disease remains uncertain. Repeated biopsies might be needed in case of irresponsive disease.

Nowadays, for daily clinical practice, the importance of receptor loss lies in preventing exposure to ineffective, potential toxic, and costly therapies and depriving the opportunity for appropriate therapies. In a previous prospective study by Amir et al. physicians changed treatment from the proposed plan in $14 \%$ of all biopsied patients [38]. This percentage also included change in treatment due to a benign lesion or malignancy from another primary origin. Of the 121 patients in the study, 41 (34\%) had discordance in at least one receptor and of them $13(32 \%)$ patients had a change in therapy. Our study design is not suitable to express the exact proportion of treatment change, since first-line treatment choices were not prospectively evaluated. However, based on the observed treatment patterns in concordant and discordant patients, we estimate that $40 \%-60 \%$ of all patients with subtype discordance would be treated differently, which is $5 \%-7 \%$ in all patients without a biopsy and 
even $30 \%$ in patients with the HR +/HER2 + subtype (Fig. 2, Supplementary table 3 ). We observed that for patients with the primary HR +/HER $2+$ subtype, the loss of HR positivity resulted in a total decline of endocrine therapy. For the loss of HER 2 positivity, $29 \%$ of patients with a change toward a TN subtype according to metastatic biopsy continued to receive HER2-targeted therapy. The prescription of HER2targeted therapy in these patients is not inherently wrong, considering spatial heterogeneity $[39,40]$. Nevertheless, it is important to examine the current metastatic receptor subtype to be aware of discordance and the possible ineffectiveness of therapies targeted to the primary subtype.

The large population of patients diagnosed with $\mathrm{ABC}$ is a strength of this study. Our observational registry allows to evaluate physicians' choices on obtaining a biopsy of metastatic site and given systemic therapies. Patient numbers were sufficient to perform multivariable analyses to find associated predictors. Furthermore, we only focused on patients diagnosed with $\mathrm{ABC}$, so that the effect of MFI and (neo-)adjuvant therapies could be included in the logistic regression analyses. Our study also has certain limitations. The biopsy site was not registered, so for patients with multiple metastatic sites, we could not distinguish the actual biopsy site. It was also not registered whether biopsies were histological samples or possibly cytological, as both types of biopsies were included in the registry. However, we expect that most of the used biopsies were histological samples, as we only included biopsies where both HR and HER2 status were completely evaluated. Reproducibility of receptor evaluation in cytological samples has been a point of discussion, but seems to be reliable, depending on the technique used [41, 42]. Another confounder in the reproducibility of HER2 receptor status is the change in HER2 testing as recommended by ASCO, introduced in a guideline in 2007, and updated in 2013 and 2018 [43-45]. Since 2007 this led to reduced false-positive HER2 tests, while the updates led to a small increase of true positive HER2 tests [46]. Although this might have influenced the discordance rates in our study for a small proportion of patients, it does not explain the higher discordance rates in the HR + /HER 2 + subtype in comparison to the other subtypes. Another limitation is that patient numbers were too low to perform a multivariable model per type of individual receptor, while our hypothesis is that these entities might have different predictors in the occurrence of subtype discordance. Nonetheless, our study provides realistic insight in biopsy rate and subtype discordance. We expect that the subgroup for evaluating the discordance rates is representative for the total population, as the distribution of primary subtype and individual receptor discordance was comparable with the total group (Table 1 and supplementary table S1). For future research, it might be interesting to evaluate the receptor subtype over repeated biopsies during $\mathrm{ABC}$ treatment, while therapeutic resistance occurs. Additionally, we emphasize the need for more research into biogenetic pathways and genetic mutations, as, in contrast to our expectations, the influence of adjuvant systemic therapies was not the reason for discordance.

\section{Conclusion}

When deciding to start systemic therapy, it is important to perform a biopsy of a metastatic site to make sure that the chosen therapy targets all active receptors. Taking a biopsy is especially important in patients diagnosed with the HR + I HER $2+$ subtype of the primary tumor, where the majority of patients experienced discordance and which may be caused by a biological cross-talk between ER and HER2.

Supplementary Information The online version contains supplementary material available at https://doi.org/10.1007/s10549-021-06472-5.

Acknowledgements We thank our SONABRE registrars of the department of Medical Oncology of Maastricht University Medical Center (MUMC+), Maastricht, the Netherlands.

Author contributions MM, KI, SG, and VTH contributed to conceptualization, methodology, and investigation; IV, FE, MD, BV, KA, MP, and LW contributed to resources; AHW performed investigation; SG performed data curation, formal analysis, and visualization; VTH performed supervision; $\mathrm{MM}$ and KI contributed to writing and preparation of the original draft; MM, KI, DL, IV, LK, FE, MD, BV, KA, MP, LW, JT, JH, AW, NP AHW, MS, SG, and VTH contributed to writing, reviewing, and editing of the manuscript.

Funding This work was supported by the Netherlands Organization for Health Research and Development (ZonMw: 80-82500-98-8003), Novartis BV, Roche, Pfizer, and Eli Lilly.

Data availability The data underlying this article will be shared on reasonable request to the corresponding author.

\section{Declarations}

Conflict of interest MM, KI, and AHW report grant of the Netherlands Organization for Health Research and Development (ZonMw: 80-82500-98-8003) and financial support by Novartis BV, Roche, Pfizer, and Eli Lilly, as listed in the funding section. IV reports grant from Pfizer. SG reports institutional grants from Novartis BV, Roche, Pfizer, Eli Lilly, and Daiichi Sankyo and personal fees from AstraZeneca. VTH reports grants and personal fees from Roche, grants and personal fees from Novartis, grants and personal fees from Pfizer, grants and personal fees from Lilly, personal fees from Accord Healthcare, grants from AstraZeneca, grants from Eisai, and grants from Daiichi Sankyo. All remaining authors have declared no conflict of interest.

Ethical approval The SONABRE Registry (NCT-03577197) was approved and the need for informed consent waived by the Medical Research Ethics Committee of Maastricht University Medical Center (METC 15-4-239). 
Open Access This article is licensed under a Creative Commons Attribution 4.0 International License, which permits use, sharing, adaptation, distribution and reproduction in any medium or format, as long as you give appropriate credit to the original author(s) and the source, provide a link to the Creative Commons licence, and indicate if changes were made. The images or other third party material in this article are included in the article's Creative Commons licence, unless indicated otherwise in a credit line to the material. If material is not included in the article's Creative Commons licence and your intended use is not permitted by statutory regulation or exceeds the permitted use, you will need to obtain permission directly from the copyright holder. To view a copy of this licence, visit http://creativecommons.org/licenses/by/4.0/.

\section{References}

1. André F, Ciruelos E, Rubovszky G, Campone M, Loibl S, Rugo HS, Iwata H, Conte P, Mayer IA, Kaufman B, Yamashita T, Lu YS, Inoue K, Takahashi M, Pápai Z, Longin AS, Mills D, Wilke C, Hirawat S, Juric D (2019) Alpelisib for PIK3CA-mutated, hormone receptor-positive advanced breast cancer. N Engl J Med 380:1929-1940. https://doi.org/10.1056/NEJMoa1813904

2. Baselga J, Campone M, Piccart M, Burris HA 3rd, Rugo HS, Sahmoud T, Noguchi S, Gnant M, Pritchard KI, Lebrun F, Beck JT, Ito Y, Yardley D, Deleu I, Perez A, Bachelot T, Vittori L, Xu Z, Mukhopadhyay P, Lebwohl D, Hortobagyi GN (2012) Everolimus in postmenopausal hormone-receptor-positive advanced breast cancer. N Engl J Med 366:520-529. https://doi.org/10. 1056/NEJMoa1109653

3. Cristofanilli M, Turner NC, Bondarenko I, Ro J, Im S-A, Masuda N, Colleoni M, DeMichele A, Loi S, Verma S, Iwata H, Harbeck N, Zhang K, Theall KP, Jiang Y, Bartlett CH, Koehler M, Slamon D (2016) Fulvestrant plus palbociclib versus fulvestrant plus placebo for treatment of hormone-receptor-positive, HER2-negative metastatic breast cancer that progressed on previous endocrine therapy (PALOMA-3): final analysis of the multicentre, doubleblind, phase 3 randomised controlled trial. Lancet Oncol 17:425439. https://doi.org/10.1016/s1470-2045(15)00613-0

4. Baselga J, Swain SM (2010) CLEOPATRA: a phase III evaluation of pertuzumab and trastuzumab for HER2-positive metastatic breast cancer. Clin Breast Cancer 10:489-491. https://doi.org/10. 3816/CBC.2010.n.065

5. Cameron D, Casey M, Press M, Lindquist D, Pienkowski T, Romieu CG, Chan S, Jagiello-Gruszfeld A, Kaufman B, Crown J, Chan A, Campone M, Viens P, Davidson N, Gorbounova V, Raats JI, Skarlos D, Newstat B, Roychowdhury D, Paoletti P, Oliva C, Rubin S, Stein S, Geyer CE (2008) A phase III randomized comparison of lapatinib plus capecitabine versus capecitabine alone in women with advanced breast cancer that has progressed on trastuzumab: updated efficacy and biomarker analyses. Breast Cancer Res Treat 112:533-543. https://doi.org/10.1007/ s10549-007-9885-0

6. Murphy CG, Morris PG (2012) Recent advances in novel targeted therapies for HER2-positive breast cancer. Anticancer Drugs 23:765-776. https://doi.org/10.1097/CAD.0b013e328352d292

7. Slamon DJ, Leyland-Jones B, Shak S, Fuchs H, Paton V, Bajamonde A, Fleming T, Eiermann W, Wolter J, Pegram M, Baselga J, Norton L (2001) Use of chemotherapy plus a monoclonal antibody against HER 2 for metastatic breast cancer that overexpresses HER2. N Engl J Med 344:783-792. https://doi.org/10.1056/nejm2 00103153441101

8. Verma S, Miles D, Gianni L, Krop IE, Welslau M, Baselga J, Pegram M, Oh D-Y, Diéras V, Guardino E, Fang L, Lu MW, Olsen S, Blackwell K (2012) Trastuzumab emtansine for HER2-positive advanced breast cancer. N Engl J Med 367:1783-1791. https://doi. org/10.1056/NEJMoa1209124

9. Robson M, Im S-A, Senkus E, Xu B, Domchek SM, Masuda N, Delaloge S, Li W, Tung N, Armstrong A, Wu W, Goessl C, Runswick S, Conte P (2017) Olaparib for metastatic breast cancer in patients with a germline BRCA mutation. N Engl J Med 377:523533. https://doi.org/10.1056/NEJMoa1706450

10. Schmid P, Adams S, Rugo HS, Schneeweiss A, Barrios CH, Iwata H, Diéras V, Hegg R, Im SA, Shaw Wright G, Henschel V, Molinero L, Chui SY, Funke R, Husain A, Winer EP, Loi S, Emens LA (2018) Atezolizumab and Nab-paclitaxel in advanced triplenegative breast cancer. N Engl J Med 379:2108-2121. https://doi. org/10.1056/NEJMoa1809615

11. Schrijver W, Suijkerbuijk KPM, van Gils CH, van der Wall E, Moelans CB, van Diest PJ (2018) Receptor conversion in distant breast cancer metastases: a systematic review and meta-analysis. J Natl Cancer Inst 110:568-580. https://doi.org/10.1093/jnci/ djx 273

12. Cardoso F, Senkus E, Costa A, Papadopoulos E, Aapro M, Andre F, Harbeck N, Aguilar Lopez B, Barrios CH, Bergh J, Biganzoli L, Boers-Doets CB, Cardoso MJ, Carey LA, Cortes J, Curigliano G, Dieras V, El Saghir NS, Eniu A, Fallowfield L, Francis PA, Gelmon K, Johnston SRD, Kaufman B, Koppikar S, Krop IE, Mayer M, Nakigudde G, Offersen BV, Ohno S, Pagani O, Paluch-Shimon S, Penault-Llorca F, Prat A, Rugo HS, Sledge GW, Spence D, Thomssen C, Vorobiof DA, Xu B, Norton L, Winer EP (2018) 4th ESO-ESMO international consensus guidelines for advanced breast cancer (ABC 4)dagger. Ann Oncol 29:16341657. https://doi.org/10.1093/annonc/mdy192

13. Dutch Breast Cancer Guideline, NABON 2012.

14. Amir E, Clemons M, Purdie CA, Miller N, Quinlan P, Geddie W, Coleman RE, Freedman OC, Jordan LB, Thompson AM (2012) Tissue confirmation of disease recurrence in breast cancer patients: pooled analysis of multi-centre, multi-disciplinary prospective studies. Cancer Treat Rev 38:708-714. https://doi. org/10.1016/j.ctrv.2011.11.006

15. Botteri E, Disalvatore D, Curigliano G, Brollo J, Bagnardi V, Viale G, Orsi F, Goldhirsch A, Rotmensz N (2012) Biopsy of liver metastasis for women with breast cancer: impact on survival. Breast (Edinburgh, Scotland) 21:284-288. https://doi.org/ 10.1016/j.breast.2011.12.014

16. Chang HJ, Han SW, Oh DY, Im SA, Jeon YK, Park IA, Han W, Noh DY, Bang YJ, Kim TY (2011) Discordant human epidermal growth factor receptor 2 and hormone receptor status in primary and metastatic breast cancer and response to trastuzumab. Jpn J Clin Oncol 41:593-599. https://doi.org/10.1093/jjco/hyr020

17. de Dueñas EM, Hernández AL, Zotano AG, Carrión RM, LópezMuñiz JI, Novoa SA, Rodríguez AL, Fidalgo JA, Lozano JF, Gasión OB, Carrascal EC, Capilla AH, López-Barajas IB, Mateu MM, de Ceballos Reyna MH, Ferrando AO, Jañez NM, Ballerini VC, Torres AA, Catalán G, Sáenz JA, Menjón S, GonzálezAngulo AM (2014) Prospective evaluation of the conversion rate in the receptor status between primary breast cancer and metastasis: results from the GEICAM 2009-03 ConvertHER study. Breast Cancer Res Treat 143:507-515. https://doi.org/10.1007/ s10549-013-2825-2

18. Erdem GU, Altundag K, Ozdemir NY, Sahin S, Demirci NS, Karatas F, Bozkaya Y, Aytekin A, Tasdemir V, Aslan AC, Sever AR, Zengin N (2017) Comparative study of receptor discordance between primary and corresponding metastatic lesions in breast cancer. J buon 22:365-376

19. Matsumoto A, Jinno H, Murata T, Seki T, Takahashi M, Hayashida T, Kameyama K, Kitagawa Y (2015) Prognostic implications of receptor discordance between primary and recurrent breast cancer. Int J Clin Oncol 20:701-708. https://doi.org/10. 1007/s10147-014-0759-2 
20. McAnena PF, McGuire A, Ramli A, Curran C, Malone C, McLaughlin R, Barry K, Brown JAL, Kerin MJ (2018) Breast cancer subtype discordance: impact on post-recurrence survival and potential treatment options. BMC Cancer 18:203. https://doi. org/10.1186/s12885-018-4101-7

21. Nishimura R, Osako T, Okumura Y, Tashima R, Toyozumi Y, Arima N (2011) Changes in the ER, PgR, HER2, p53 and Ki-67 biological markers between primary and recurrent breast cancer: discordance rates and prognosis. World J Surg Oncol 9:131. https://doi.org/10.1186/1477-7819-9-131

22. Shiino S, Kinoshita T, Yoshida M, Jimbo K, Asaga S, Takayama S, Tsuda H (2016) Prognostic impact of discordance in hormone receptor status between primary and recurrent sites in patients with recurrent breast cancer. Clin Breast Cancer 16:e133-140. https://doi.org/10.1016/j.clbc.2016.05.014

23. Broom RJ, Tang PA, Simmons C, Bordeleau L, Mulligan AM, O'Malley FP, Miller N, Andrulis IL, Brenner DM, Clemons MJ (2009) Changes in estrogen receptor, progesterone receptor and Her-2/neu status with time: discordance rates between primary and metastatic breast cancer. Anticancer Res 29:1557-1562

24. Heitz F, Barinoff J, du Bois O, Hils R, Fisseler-Eckhoff A, Harter P, Heitz J, Willenbrock K, Traut A, du Bois A (2013) Differences in the receptor status between primary and recurrent breast cancer-the frequency of and the reasons for discordance. Oncology 84:319-325. https://doi.org/10.1159/000346184

25. Ilgun S, Sarsenov D, Erdogan Z, Ordu C, Celebi F, Nur Pilanci K, Ozturk A, Selamoglu D, Alco G, Aktepe F, Eralp Y, Tuzlali S, Ozmen V (2016) Receptor discordance rate and its effects on survival in primary and recurrent breast cancer patients. J Buon 21:1425-1432

26. Liedtke C, Broglio K, Moulder S, Hsu L, Kau SW, Symmans WF, Albarracin C, Meric-Bernstam F, Woodward W, Theriault RL, Kiesel L, Hortobagyi GN, Pusztai L, Gonzalez-Angulo AM (2009) Prognostic impact of discordance between triple-receptor measurements in primary and recurrent breast cancer. Ann Oncol 20:1953-1958. https://doi.org/10.1093/annonc/mdp263

27. Criscitiello C, André F, Thompson AM, De Laurentiis M, Esposito A, Gelao L, Fumagalli L, Locatelli M, Minchella I, Orsi F, Goldhirsch A, Curigliano G (2014) Biopsy confirmation of metastatic sites in breast cancer patients: clinical impact and future perspectives. Breast Cancer Res 16:205. https://doi.org/ $10.1186 /$ bcr3630

28. Dekker TJ, ter Borg S, Hooijer GK, Meijer SL, Wesseling J, Boers JE, Schuuring E, Bart J, van Gorp J, Bult P, Riemersma SA, van Deurzen CH, Sleddens HF, Mesker WE, Kroep JR, Smit VT, van de Vijver MJ (2015) Quality assessment of estrogen receptor and progesterone receptor testing in breast cancer using a tissue microarray-based approach. Breast Cancer Res Treat 152:247-252. https://doi.org/10.1007/s10549-015-3444-x

29. Griggs JJ, Hamilton AS, Schwartz KL, Zhao W, Abrahamse PH, Thomas DG, Jorns JM, Jewell R, Saber ME, Haque R, Katz SJ (2017) Discordance between original and central laboratories in ER and HER2 results in a diverse, population-based sample. Breast Cancer Res Treat 161:375-384. https://doi.org/10.1007/ s10549-016-4061-z

30. Pusztai L, Viale G, Kelly CM, Hudis CA (2010) Estrogen and HER-2 receptor discordance between primary breast cancer and metastasis. Oncologist 15:1164-1168. https://doi.org/10.1634/ theoncologist.2010-0059

31. Turashvili G, Brogi E (2017) Tumor heterogeneity in breast cancer. Front Med (Lausanne) 4:227. https://doi.org/10.3389/ fmed.2017.00227

32. Ellsworth RE, Blackburn HL, Shriver CD, Soon-Shiong P, Ellsworth DL (2017) Molecular heterogeneity in breast cancer: state of the science and implications for patient care. Semin Cell Dev Biol 64:65-72. https://doi.org/10.1016/j.semcdb.2016.08.025
33. Bertucci F, Ng CKY, Patsouris A, Droin N, Piscuoglio S, Carbuccia N, Soria JC, Dien AT, Adnani Y, Kamal M, Garnier S, Meurice G, Jimenez M, Dogan S, Verret B, Chaffanet M, Bachelot T, Campone M, Lefeuvre C, Bonnefoi H, Dalenc F, Jacquet A, De Filippo MR, Babbar N, Birnbaum D, Filleron T, Le Tourneau C, André F (2019) Genomic characterization of metastatic breast cancers. Nature 569:560-564. https://doi.org/ $10.1038 / \mathrm{s} 41586-019-1056-\mathrm{Z}$

34. Welch DR (2016) Tumor heterogeneity-A 'Contemporary Concept' founded on historical insights and predictions. Can Res 76:4. https://doi.org/10.1158/0008-5472.CAN-15-3024

35. Schedin TB, Borges VF, Shagisultanova E (2018) Overcoming therapeutic resistance of triple positive breast cancer with CDK4/6 inhibition. Int J Breast Cancer 2018:7835095-7835095. https:// doi.org/10.1155/2018/7835095

36. Schettini F, Buono G, Cardalesi C, Desideri I, De Placido S, Del Mastro L (2016) Hormone receptor/human epidermal growth factor receptor 2-positive breast cancer: Where we are now and where we are going. Cancer Treat Rev 46:20-26. https://doi.org/ 10.1016/j.ctrv.2016.03.012

37. Montemurro F, Di Cosimo S, Arpino G (2013) Human epidermal growth factor receptor 2 (HER2)-positive and hormone receptorpositive breast cancer: new insights into molecular interactions and clinical implications. Ann Oncol 24:2715-2724. https://doi. org/10.1093/annonc/mdt287

38. Amir E, Miller N, Geddie W, Freedman O, Kassam F, Simmons C, Oldfield M, Dranitsaris G, Tomlinson G, Laupacis A, Tannock IF, Clemons M (2012) Prospective study evaluating the impact of tissue confirmation of metastatic disease in patients with breast cancer. J Clin Oncol 30:587-592. https://doi.org/10.1200/JCO. 2010.33.5232

39. Kalimutho M, Nones K, Srihari S, Duijf PHG, Waddell N, Khanna KK (2019) Patterns of Genomic Instability in Breast Cancer. Trends Pharmacol Sci 40:198-211. https://doi.org/10.1016/j.tips. 2019.01.005

40. Yates LR, Gerstung M, Knappskog S, Desmedt C, Gundem G, Van Loo P, Aas T, Alexandrov LB, Larsimont D, Davies H, Li Y, Ju YS, Ramakrishna M, Haugland HK, Lilleng PK, Nik-Zainal S, McLaren S, Butler A, Martin S, Glodzik D, Menzies A, Raine K, Hinton J, Jones D, Mudie LJ, Jiang B, Vincent D, Greene-Colozzi A, Adnet P-Y, Fatima A, Maetens M, Ignatiadis M, Stratton MR, Sotiriou C, Richardson AL, Lønning PE, Wedge DC, Campbell PJ (2015) Subclonal diversification of primary breast cancer revealed by multiregion sequencing. Nat Med 21:751-759. https://doi.org/ 10.1038/nm.3886

41. Ferguson J, Chamberlain P, Cramer HM, Wu HH (2013) ER, PR, and Her2 immunocytochemistry on cell-transferred cytologic smears of primary and metastatic breast carcinomas: a comparison study with formalin-fixed cell blocks and surgical biopsies. Diagn Cytopathol 41:575-581. https://doi.org/10.1002/dc.22897

42. Shabaik A, Lin G, Peterson M, Hasteh F, Tipps A, Datnow B, Weidner N (2011) Reliability of Her2/neu, estrogen receptor, and progesterone receptor testing by immunohistochemistry on cell block of FNA and serous effusions from patients with primary and metastatic breast carcinoma. Diagn Cytopathol 39:328-332. https://doi.org/10.1002/dc.21389

43. Wolff AC, Hammond ME, Hicks DG, Dowsett M, McShane LM, Allison KH, Allred DC, Bartlett JM, Bilous M, Fitzgibbons P, Hanna W, Jenkins RB, Mangu PB, Paik S, Perez EA, Press MF, Spears PA, Vance GH, Viale G, Hayes DF (2013) Recommendations for human epidermal growth factor receptor 2 testing in breast cancer: American Society of Clinical Oncology/College of American Pathologists clinical practice guideline update. J Clin Oncol 31:3997-4013. https://doi.org/10.1200/jco.2013.50.9984

44. Wolff AC, Hammond ME, Schwartz JN, Hagerty KL, Allred DC, Cote RJ, Dowsett M, Fitzgibbons PL, Hanna WM, Langer A, 
McShane LM, Paik S, Pegram MD, Perez EA, Press MF, Rhodes A, Sturgeon C, Taube SE, Tubbs R, Vance GH, van de Vijver M, Wheeler TM, Hayes DF (2007) American Society of Clinical Oncology/College of American Pathologists guideline recommendations for human epidermal growth factor receptor 2 testing in breast cancer. Arch Pathol Lab Med 131:18-43. https://doi.org/ 10.5858/2007-131-18-asocco

45. Wolff AC, Hammond MEH, Allison KH, Harvey BE, Mangu PB, Bartlett JMS, Bilous M, Ellis IO, Fitzgibbons P, Hanna W, Jenkins RB, Press MF, Spears PA, Vance GH, Viale G, McShane LM, Dowsett M (2018) Human Epidermal growth factor receptor 2 testing in breast cancer: American Society of Clinical Oncology/College of American Pathologists Clinical Practice guideline focused update. J Clin Oncol 36:2105-2122. https://doi.org/10. 1200/jco.2018.77.8738

46. Lim TH, Lim AS, Thike AA, Tien SL, Tan PH (2016) Implications of the updated 2013 American Society of Clinical Oncology/ College of American Pathologists Guideline recommendations on human epidermal growth factor receptor 2 gene testing using immunohistochemistry and fluorescence in situ hybridization for breast cancer. Arch Pathol Lab Med 140:140-147. https://doi.org/ 10.5858/arpa.2015-0108-OA

Publisher's Note Springer Nature remains neutral with regard to jurisdictional claims in published maps and institutional affiliations.

\title{
Authors and Affiliations
}

\author{
Marissa Meegdes ${ }^{1,2}$ (D) Khava I. E. Ibragimova ${ }^{1,2}$ - Dorien J. A. Lobbezoo ${ }^{1} \cdot$ Ingeborg J. H. Vriens ${ }^{1,2}$. \\ Loes F. S. Kooreman ${ }^{2,3} \cdot$ Frans L. G. Erdkamp ${ }^{4}$. M. Wouter Dercksen ${ }^{5}$ B Birgit E. P. J. Vriens ${ }^{6} \cdot$ Kirsten N. A. Aaldering $^{7}$. \\ Manon J. A. E. Pepels ${ }^{8} \cdot$ Linda M. H. van de Winkel ${ }^{9}$. Jolien Tol $^{10}$ • Joan B. Heijns ${ }^{11}$. Agnes J. van de Wouw ${ }^{12}$. \\ Natascha A. J. B. Peters ${ }^{13}$. Ananda Hochstenbach-Waelen ${ }^{1}$. Marjolein L. Smidt ${ }^{2,14}$. Sandra M. E. Geurts ${ }^{1,2}$. \\ Vivianne C. G. Tjan-Heijnen ${ }^{1,2}$
}

1 Department of Internal Medicine, Division of Medical Oncology, Maastricht University Medical Centre, Maastricht, The Netherlands

2 GROW School for Oncology and Developmental Biology, Maastricht University, Maastricht, The Netherlands

3 Department of Pathology, Maastricht University Medical Centre, Maastricht, The Netherlands

4 Department of Internal Medicine, Zuyderland Medical Centre, Sittard-Geleen, The Netherlands

5 Department of Internal Medicine, Máxima Medical Centre, Veldhoven, The Netherlands

6 Department of Internal Medicine, Catharina Hospital, Eindhoven, The Netherlands

7 Department of Internal Medicine, Laurentius Hospital, Roermond, The Netherlands
8 Department of Internal Medicine, Elkerliek Hospital, Helmond, The Netherlands

9 Department of Internal Medicine, St Anna Hospital, Geldrop, The Netherlands

10 Department of Internal Medicine, Jeroen Bosch Ziekenhuis, Den Bosch, The Netherlands

11 Department of Internal Medicine, Amphia Hospital, Breda, The Netherlands

12 Department of Internal Medicine, Viecuri Medical Centre, Venlo, The Netherlands

13 Department of Internal Medicine, St. Jans Gasthuis, Weert, The Netherlands

14 Department of Surgery, Maastricht University Medical Centre, Maastricht, The Netherlands 